\title{
Elephantgrass, a tropical grass for cutting and grazing
}

Antonio Vander Pereira ${ }^{1 *}{ }^{\circ}$, Mário de Andrade Lira ${ }^{2 * *}$, Juarez Campolina Machado ${ }^{1}$, Carlos Augusto de Miranda Gomide ${ }^{1} \oplus$, Carlos Eugenio Martins ${ }^{1}{ }^{\oplus}$,

Francisco José da Silva Lédo ${ }^{1} \odot$, Rogério Figueiredo Daher ${ }^{3}$

\footnotetext{
1'Embrapa de Gado de Leite, Juiz de Fora, MG, Brasil. E-mail: vander.pereira@embrapa.br; juarez.machado@embrapa.br; carlos.gomide@embrapa.br; carlos.eugenio@embrapa.br; francisco.ledo@embrapa.br

${ }^{2}$ Universidade Federal Rural de Pernambuco, Departamento de Zootecnia, Recife, PE, Brasil

${ }^{3}$ Universidade Estadual do Norte Fluminense Darcy Ribeiro, Centro de Ciências e Tecnologias Agropecuárias, Campos dos Goytacazes, RJ, Brasil. E-mail: rogdaher@uenf.br
}

ABSTRACT: Elephantgrass (Pennisetum purpureum Schum. syn. Cenchrus purpureus) is one of the most important forage plants worldwide, cultivated in almost all tropical and subtropical regions due to its high potential for dry matter production, nutritional value, acceptability by different animal species and categories, vigor, and persistence. It has shown great potential for biomass energy production and other forms of non-forage use. This study aimed to review the current knowledge about the cultivation and use elephantgrass focused on pasture and silage. The study also describes the main morphological, genetic, and cytogenetic characteristics of the species, and methods and strategies for obtaining improved cultivars. The release of dwarf type cultivars for grazing and cultivars with high-yield potential for silage has increased the interest in the cultivation of elephantgrass in the beef and dairy cattle production.

Key words: forage; improvement; pasture; silage

\section{Capim elefante, uma planta forrageira tropical para corte e pastejo}

RESUMO: O capim-elefante (Pennisetum purpureum Schum. sin. Cenchrus purpureus) é uma das mais importantes plantas forrageiras, sendo cultivado em quase todas as regiões tropicais e subtropicais do globo devido ao seu elevado potencial de produção de forragem, valor nutritivo, aceitabilidade por diferentes categorias e espécies de animais, vigor e persistência. 0 capim elefante também enorme potencial para produção de biomassa energética e outras formas de uso não forrageiro. 0 objetivo deste trabalho foi revisar o conhecimento atual sobre o cultivo e uso do capim elefante, principalmente como pastagem e na forma de silagem. $O$ estudo também descreve as principais características morfológicas, genéticas e citogenéticas, bem como os métodos e estratégias para obtenção de cultivares melhoradas. 0 desenvolvimento de cultivares melhoradas de porte baixo, específicas para pastejo, e de elevado potencial produtivo, para ensilagem, tem resultado no aumento de interesse pelo cultivo dessa forrageira na produção de carne e leite.

Palavras-chave: forragem; melhoramento; pastagem; silagem

\footnotetext{
*Antonio Vander Pereira - E-mail: vander.pereira@embrapa.br (Corresponding author)

** In memoriam

Associate Editor: Mércia Virginia Ferreira dos Santos
} 


\section{Introduction}

Elephantgrass is one of the most important forage species in the world. It has been grown in almost all tropical and subtropical regions of the globe due to its high potential for forage accumulation, nutritive value, acceptability by different animal species, vigor, and persistence. Another factor favorable to its use is the low incidence of pests and diseases compared to other species. The elephant grass is considered the species with greater photosynthetic efficiency in relation to others forage grasses and with great yield capacity and accumulation of dry matter of good nutritional quality (Coombs et al., 1973). It is maily used for cut-and-carry forage systems, but it can also be used for silage (Pereira et al. 2016; 2021), rotational stocking (Chaves et al., 2013; Gomide et al., 2015), and for biomass energy production (Rocha et al., 2017). The species is highly demanding in soil fertility and is not well adapted to areas subjected to flooding or long waterlogging periods (Bogdan, 1977). It considered is a rustic grass, with good tolerance to trampling and medium resistance to cold, drought, and fire (Evangelista \& Rocha, 1990).

\section{History - from Discovery in Africa to Introduction in Brazil}

Elephantgrass occurs naturally in several African countries, and its first taxonomic classification was made in 1827 when it was described as Pennisetum purpureum Schumach (Tcacenco \& Botrel, 1997), and lately reclassified as Cenchrus pupureus. The plant was already widely used as forage in several areas of Africa, where is known by different regional names, including Zinyamunga in Zimbabwe. In 1903, the plant was collected by Colonel Napier de Bulawayo, who took it to the Ministry of Agriculture of Rhodesia (nowadays Zimbabwe) to explore the possibility of using for feeding commercial cattle (Boonman, 1993). In 1910, a publication in the Rhodesian Agricultural Journal (vol. vii, p. 1398) presented the new forage grass, which was described as Zinyamunga or Napier's forage. From that point, elephantgrass also became known as Napier grass.

Due to the large production of green matter and good acceptability by animals, this forage plant was quickly disseminated throughout all tropical and subtropical regions of the world. The elephantgrass was introduced in the United States in 1913, and from there, it was disseminated to almost the entire Americas and other continents. In Brazil, it was introduced in 1920 from Cuban cuttings, and its first introduction and dissemination throughout the country were described in great detail by Granato (1924), whose paper is interesting to read due to its historical record value.

\section{Center of Origin and Diversity}

Tropical Africa is identified as the center of origin and diversity of elephantgrass (Stapt \& Hubbard, 1934), with the territories of Guinea, Mozambique, Angola, Zimbabwe, and southern Kenya as the main concentration areas of the genetic variability of this forage plant. Natural populations of the species are found between latitudes $10^{\circ} \mathrm{N}$ and $10^{\circ} \mathrm{S}$ and from the sea level up to $2,000 \mathrm{~m}$ in altitude. The most frequent habitats of the species are the fertile valleys with precipitation above $1,000 \mathrm{~mm}$, mainly in watercourses banks, but some varieties of this plant are also found in the areas of savanna (Brunken, 1977).

\section{Plant Description}

Pennisetum purpureum, syn. Cenchrus purpureus is a species of perennial tropical grass with wide phenotypic variation in relation to botanical characteristics and forage importance (Figure 1). Several studies have described the variability of morphological, phenological, cytogenetic, adaptive, productive, and bromatological characteristics of elephantgrass under different management conditions (Brunken, 1977; Bogdan, 1977; Tcacenco \& Lance, 1992; Pereira, 1993; Xavier et al., 1995; Pereira et al., 2001; Techio et al., 2002; Singh et al., 2013).

The phenotypic variation between ecotypes presents contrasting levels, thus studies subdivided the species into different morphological groups. Proposals for dividing the variability were proposed considering the presence of hair (Bogdan, 1977), stem diameter, tussock shape, and flowering season (Pereira, 1993). Maire (1952) suggested the subdivision of $P$. purpureum into the three-following subspecies: ssp. benthamii, ssp. purpureum, and ssp. flexipica. However, the continuous nature of the variation and the genetic compatibility between the different ecotypes did not support the intraspecific division (Brunken, 1977).

The main descriptive characteristics of the species are perennial vegetative cycle, upright growth, tussocks with 10 to 40 tillers, stems with 15 to 25 erect, cylindrical, glabrous, and full nodes, internodes with 15 to $20 \mathrm{~cm}$ in length and diameter up to $2.5 \mathrm{~cm}$, plant size ranging from $80 \mathrm{~cm}$ (dwarf type) to $6.0 \mathrm{~m}$ (tall type), and thick rhizomes. The grass present alternate leaves and can reach up to $1.25 \mathrm{~m}$ in length and 4.0 $\mathrm{cm}$ in width; central vein broad and lighter in color; woolly, thin, striated sheath; short and ciliated ligule. The terminal inflorescence is of the panicle type, purplish, compact, and cylindrical, with length ranging from 10 to $30 \mathrm{~cm}$, and diameter from 1.5 to $3.0 \mathrm{~cm}$. The panicle rachis is pubescent, densely flowered with spikelets with long bristles, isolated or

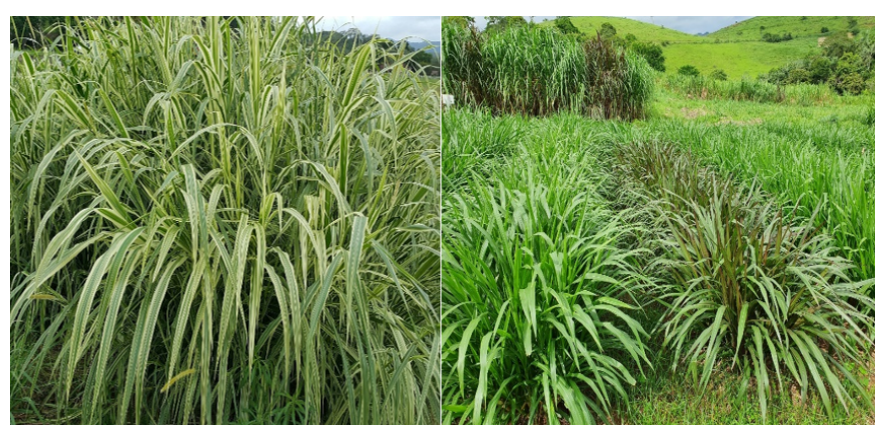

Figure 1. Genetic variability in elephantgrass indicated by different plant height and leaf colors. 
in groups; the flowers can be masculine and bisexual; the first glume is shorter than the spikelet and may be small and even absent. The second glume is shorter or equal to the fertile lemma, including the palea. The seeds or caryopses are very small, and, after ripening, they easily detach from the panicle, hampering the harvesting.

\section{Taxonomy}

Elephantgrass belongs to the family Poaceae, subfamily Panicoideae, tribe Paniceae, genus Pennisetum, and section Penicillaria. The tribe Paniceae comprises the most important genera of tropical forage plants, such as Brachiaria (syn. Urochloa), Panicum (syn. Megathyrsus), Melinis, Setaria, Axonopus, and Acroceras. According to Tcacenco \& Botrel (1997), since its original description, elephantgrass has gone through a series of denominations, including: $P$. macrostachyum Benth; P. benthamii Steud, Ciymnothrix nitens Anderss, P. nitens (Anderss.) Hack; P. flexispica K. Schum; P. benthamii var. sambiense Hack; $P$. benthamii var. nudum Hack; P. benthamii var. ternatum Hack; P. fiavonicum Leeke; $P$. pruinosum Leeke; $P$. pallescens Leeke; $P$. lachnorrhachis A. Peters; P. purpureum subs. flexispica (K. Schum.) Maire and Weiler; P. purpureum subsp, benthamii (Steud.) Malre and Weiller.

Recent phylogenetic studies based on morphological and molecular characters have shown that the species of Pennisetum, Cenchrus, and Odontelytrum have a common origin. Based on these studies, taxonomists have proposed the existence of only the genus Cenchrus, comprising all species assigned to the three genera (Chemisquy et al., 2010; Gutiérrez, 2015). Consequently, a new nomenclature was also presented for species previously belonging to the genera Pennisetum and Odontelytrum, and thus a change in the name of elephantgrass to the homotypic synonym Cenchrus purpureus (Schumach.) Morrone has been proposed.

\section{Cytogenetics}

The germplasm of the genus Pennisetum consists of three gene sets (Harlan \& De Wet, 1971). Millet (P. glaucum) with 2n $=2 \mathrm{x}=14$ and two other wild diploid species ( $P$. mollissimum and $P$. violaceum) make up the primary gene pool. In the second group, there is the elephantgrass ( $P$. purpureum Schum.) with $2 \mathrm{n}=4 \mathrm{x}=28$ and, in the tertiary set, the remaining species (Harlan \& De Wet, 1971; Martel et al., 2004).

Elephantgrass is an allotetraploid species with $A^{\prime} A^{\prime} B B$ genomes and normally diploid (Jauhar, 1981; Techio et al., 2002; Barbosa et al., 2003; Martel et al., 2004). Several studies have shown that the chromosomes of the $A^{\prime}$ genome of elephantgrass are homologous to those of the A genome of millet (genome $A A$ ), and therefore this species is considered one of its ancestors (Jauhar, 1981; Reis et al., 2014). During the evolutionary process of the two species, genomes $A$ and $A^{\prime}$ diverged from the ancestral $A$ genome by increasing the size of chromosomes in P. glaucum and due to rearrangements and/ or deletions in the $P$. purpureum genome. The reorganizations in the ancestral A genome during evolution formed the $A^{\prime}$ subgenome of $P$. purpureum (Martel et al., 2004; Reis et al., 2014; Animasaun et al., 2019). The origin of the chromosomes of the $B$ genome has not been identified yet.

These two species are closely related and can be easily crossed generating sterile hybrids that can be maintained by vegetative propagation. This triploid hybrid has $2 n=3 x$ $=21$ chromosomes and $A^{\prime} A^{\prime}$ genomes, with phenotypic characteristics similar to elephantgrass due to the greater genetic contribution of this species (2/3 of the chromosomes) and the dominance of the genome $B$ of $P$. purpureum over the genome A of $P$. glaucum (Gonzales \& Hanna, 1984). Restoring the fertility of this hybrid can be achieved by duplicating the chromosome set and obtaining a hexaploid hybrid (Hanna, 1981; Hanna et al., 1984; Dujardin \& Hanna, 1985; Barbosa et al., 2003). This polyploid produces larger seeds than those of elephantgrass and is considered promising for seed propagation (Osgood et al., 1997). These hybrids have been studied in several research centers, and there are two commercial cultivars of polyploidy hybrids in Brazil.

\section{Climate Requirements and Environmental Adaptation}

Elephantgrass develops best at temperatures between 28 and $33{ }^{\circ} \mathrm{C}$ (Ferraris et al., 1986), considerably slowing development below $15{ }^{\circ} \mathrm{C}$, with limited growth at temperatures below $10{ }^{\circ} \mathrm{C}$ (Jacques, 1994). The aerial part may dry out due to frost but regrow as temperature and humidity increase. According to Bogdan (1977) the favourable daylight duration for the vegetative development varies from 12 to 13 hours (Bogdan, 1977). It can be grown from sea level to approximately 2,000 m altitude (Rodrigues \& Rodrigues, 1997).

The species is highly demanding concerning soil fertility and is not adapted to low $\mathrm{pH}$ and high aluminum content conditions. However, studies conducted by Martins et al. (2010) revealed differences between cultivars for tolerance to toxic aluminum. Although the elephantgrass can be grown in different soil types, it grows best in areas with deep, well-drained soils and $\mathrm{a} \mathrm{pH}$ in the range of 4.5 to 8.2 , as long as fertility is adequate (Fonseca \& Martuscello, 2010). Regarding the topography, it can be cultivated on land with slopes up to $25 \%$, as above this limit, it can favor soil erosion due to its high size and erect growth habit.

Elephantgrass has a vigorous and deep root system, as well as good transpiration efficiency in situations of water stress (Liang et al., 2018), which gives it tolerance to moderate drought. The species, however, does not adapt well to waterlogged soils or areas with prolonged flooding. Elephantgrass is seasonal forage, with $70-80 \%$ of yield concentrated in the rainy season. Thus, is important to consider both volume of precipitation and the distribution of rainfall throughout the year. 


\section{Biological Nitrogen Fixation}

Biological nitrogen fixation (BNF) is an important process for greater sustainability in elephantgrass cultivation. It has been reported that this forage plant has the potential to be associated with growth-promoting microorganisms, including the endophytic diazotrophic bacteria. The contributions of $\mathrm{N}$ derived from BNF can vary from 30 to $45 \%$ of the plant requirements (Quesada, 2005; Morais et al., 2012), representing about 50 to $130 \mathrm{~kg} / \mathrm{ha}$ of nitrogen. This BNF potential can be explained by the large number of diazotrophic bacteria that colonize the forage plant, as well as by the high efficiency of the plant-bacterial interaction. According to Kirchhof et al. (1997), only the presence of bacteria does not necessarily mean that they are efficient in fixing $\mathrm{N}$ and that plants can obtain significant contributions from biologically fixed $\mathrm{N}$.

The benefit of the potential BNF is to contribute to positive energy balance of the systems, since the industrial process of nitrogen fertilizer production uses large amounts of fossil energy (Morais et al., 2018). Studies on isolation, identification, and selection of diazotrophic bacteria have been conducted to obtain highly efficient strains in promoting the growth of elephantgrass (Oliveira et al., 2002).

\section{Flowering and Seeds}

The elephantgrass is a short-day obligate flowering plant, but the process is also affected by other environmental factors such as soil temperature and humidity. According to Hanna et al. (2004), the species requires $11 \mathrm{~h}$ of light or less for floral induction. The reduction of temperatures and rainfall also act as inducing factors of flowering. In southeastern Brazil, flowering normally occurs between March and August, a period with milder temperatures, short days, and low rainfall. According to Xavier et al. (1995) and Pereira (1993), the species can be divided into three groups of genotypes related to the flowering time: early (March and April), intermediate (April and May), and late (June to August). In natural conditions, the lack of overlapping of the flowering period between these groups can lead to temporal reproductive isolation between genotypes, especially between the early and late-flowering type. Thus, the maintenance of gene flow within the species may depend on pollen conservation or flowering induction by controlling environmental factors or using phytohormones.

In the inflorescences, the stigmas emerge from the upper part to the base of the panicles. The plant is protogynous, with the first stigmas being receptive from seven to nine days before the opening of the anthers and remaining fertile for three to four days (Pereira et al., 1999). This characteristic hinders self-fertilization in the same panicle while facilitates controlled crossings. In addition to protogyny, genotypic selfincompatibility acts as a mechanism that promotes crossfertilization. Elephantgrass produces very small seeds or caryopses, and after ripening, easily detach from the panicle and are disseminated by the wind (Figure 2). Identifying

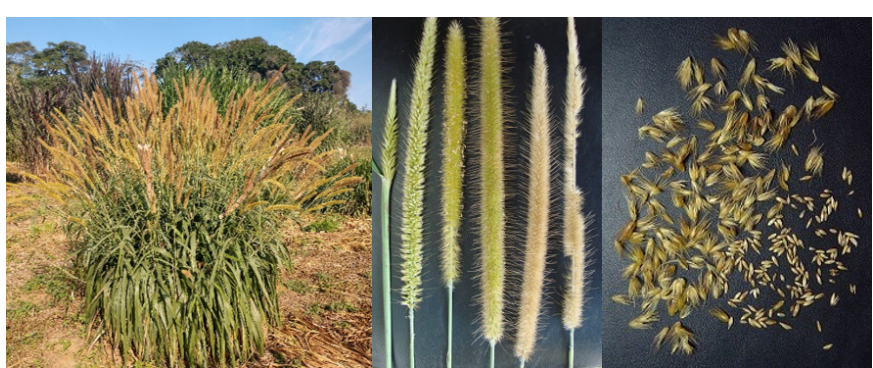

Figure 2. Flowering of elephantgrass, showing the stages of development and seed production.

genetic sources of resistance to dehiscence should facilitate the process of seed harvesting.

\section{Propagation Forms}

Elephantgrass can be grown through mature vegetative parts (stems and rhizomes) and seeds. Although rhizomes can be used for planting, the difficulties involved for obtaining this plant material contribute to little usage compared to the use of stem cuttings.

Propagation through stems cuttings is the most common form of cultivation, and has the advantage of resulting in uniform populations, maintaining the genotypic constitution of the clones. The species is well suited to vegetative propagation, with majority of the stem buds presenting sprouting potential. This propagation method, however, can be considered disadvantageous due to the difficulty in storing stems for long periods after harvest, higher transport and planting costs, as well as the lack of a public or private system that sells propagules with good sanitary quality and guaranteed varietal purity for planting in large areas.

The species is allogamous and produces a large number of viable seeds that can be stored for a long time, maintaining their germinative power. However, considering that most cultivars are clones obtained by vegetative propagation, the seeds produced by these populations are generated by selffertilization and, consequently, generate plants with low vigor that should not be used for cultivation. Additionally, the seeds are very small and dehiscent, which makes harvesting a challenging process.

\section{Germplasm and Genetic Variability}

The genetic variability of a species can be assessed the germplasm level, considering the total existing variability, and at the genetic resource level, comprising the available or known genetic variation and has current and future economic or biological value.

Germplasm can be conserved in in situ and ex-situ. Conservation in situ considers its maintenance in ecosystems and habitats where the species occurs naturally. This conservation model is considered the most important because it provides adequate conditions for the natural continuation of the genetic evolution process. The preservation ex-situ corresponds to germplasm maintenance outside its natural 
environment, allowing the use of the genetic resources in breeding programs.

Considering that it is an exotic species in Brazil, conservation ex-situ in germplasm banks is the necessary alternative since it is impossible to guarantee the accessibility and maintenance of the species' natural habitat, which are in several African countries

The germplasm of elephant grass can be conserved through seeds (conservation of the gene pool) or individual plants (clonal maintenance). The disadvantage of preserving seeds is the impossibility of maintaining genetic combinations of primary interest, which is achieved by vegetative propagation. Thus, accessions to the main germplasm banks of this forage plant are preserved by cultivation under field conditions. Considering that most accessions are clones, to reduce the risk of genetic loss due to the occurrence of natural factors such as excessive rainfall, drought, pest attack, diseases, fire, animals, among others, it is recommended that each genotype are represented by more than one tussock or experimental replicate.

Research institutions in several countries maintain germplasm banks of the elephantgrass. In Brazil, the two main germplasm banks are located at Embrapa Dairy Cattle (120 accessions) and the Agronomy Institute of Pernambuco - IPA (81 accessions). The accessions of these banks are characterized by a set of botanical-agronomic descriptors and are available for national and international exchange.

The bank accessions concentrate a wide range of characters of forage importance and presents genetic variability for developing improved cultivars (Cavalcante and Lira, 2010; Pereira et al., 2017).

\section{Genetic Characteristics and Breeding}

Some characteristics of the elephantgrass must be considered when choosing breeding strategies, as they can facilitate or streamline the selection processes.

Seed Production - the elephantgrass produces a large number of seeds with good germination capacity. The seeds are small in size and can maintain germinative power for several years as long as they are properly stored in cold chambers.

Hybridization and Self-fertilization - the species can produce seeds through crossbreeding and self-fertilization, enabling different breeding strategies. Since it is an allogamous species, although the crossings allow obtaining segregating progenies, self-fertilization results in loss of vigor in endogamous progenies (inbreeding).

Self-fertilization promotes the expression of recessive alleles that are "hidden" in the heterozygous condition, many of them with a deleterious effect resulting in loss of vigor and fertility. The self-fertilization, however, allows discovering recessive genes of forage interest, such as the dwarfism (dwarf) gene, which promotes the reduction of the plant size by reducing the length of the internodes of stems. This gene has enabled the development of dwarf-type cultivars adapted to grazing, such as the Mott (Sollenberger et al., 1989) and BRS Kurumi (Pereira et al., 2017).
Protogynous Flowering - male and female flowers occur in the same inflorescence. However, the risk of natural selfpollination is low since the species has self-incompatibility and the flowering of the stigmas occurs before the opening of the anthers. According to Pereira et al. (1999), the protogyny interval in elephantgrass varies from six to nine days.

Number of Inflorescences - each plant develops several stems with terminal and axillary inflorescence. This characteristic facilitates to carry out different crossings in the same plant.

Inflorescence Size - panicles with 10 to $30 \mathrm{~cm}$ with multiple flowers, producing a large number of seeds.

Flowering Period - the species has a long and gradual flowering period, which favors crossings between materials with non-coincident flowering peaks.

Pollen Production - elephantgrass produces pollen in abundance, a characteristic that favors the effectiveness and multiplicity of crossings carried out with a certain genotype.

Vegetative Propagation - the species shows excellent adaptation to vegetative propagation, allowing the cultivation and replication of plants with desirable genotypic combination.

Vegetative Cycle - the elephantgrass has a perennial cycle, which allows the breeder to use the same plant at different times and multiple evaluations over the years.

Genetic Variability - the evolution of the species in a great diversity of environments has enabled the development of wide genetic variability in the germplasm to be used in breeding programs.

Intra and Interspecific Crossings - crossings are carried out thoroughly by protecting the inflorescences. The possibility of obtaining hybrids with other species, mainly with millet favors the combination of different desirable characteristics.

\section{Genetic Improvement}

For thousands of years, humans, initially intuitively, and recently based on scientific knowledge, have practiced plant breeding. From the discovery of agriculture, people began to select plant seeds of great interest, contributing to the modification of several characteristics and obtaining more productive cultivars an/or higher nutritional value. From the genetic discoveries, the selection and hybridization of plants started to consider scientific concepts, resulting in higher speed in achieving improved cultivars.

In general, plant breeding can be defined as the art and science of using scientific principles and specific knowledge about a certain species to combine genotypes to obtain progenies with desirable characteristics.

According to Breseghello \& Coelho (2013), breeding methods can be grouped into three categories: 1) methods based on the selection of genotypic materials existing in nature or traditional varieties; 2 ) methods based on controlled crossings followed by the selection of progenies with the desirable recombination of the parental genes; and 3) methods based on assisted recombination by selecting specific genes through molecular tools. The choice of the method for each 
species will depend on the genetic variability, the level of intervention previously practiced on the germplasm, and the improvement goal.

The genetic improvement of elephantgrass is at an early stage of exploring germplasm variability, and the interest of the species both for forage use and as a source of biomass energy is increasing. Although the three methods can be considered for the species, the selection of germplasm and the accomplishment of targeted crossings are simpler methods; therefore, they can lead to faster success in obtaining improved cultivars. Details of the improvement strategies for this forage plant are presented by Pereira et al. (2001) and Lira et al. (2010).

Considering the wide variability of the elephantgrass germplasm, the genetic and reproductive characteristics, and the possibility of performing interspecific crossings, it is possible to obtain improved cultivars with greater yield potential, better nutritive value, adaptation to different environmental conditions, production systems, and usages potential.

\section{Genotype Selection}

Breeding based on the selection of genotypes collected in the diversity centers and on traditional varieties is the simplest method, indicated for species with wide genetic variability. This has been the main breeding method applied to several tropical forage species, such as Brachiaria and Panicum, to obtain most of the varieties released. However, this strategy tends to run out quickly as it is not always possible to find in nature genotypes that bring together a set of characters of forage importance that surpass those under cultivation. Often, the desirable attributes are distributed among different sources of genetic variation, increasing the need of performing crossings to obtain improved cultivars.

Therefore, the second stage of the breeding process is the recombination of the variability sources. Germplasm banks of elephantgrass are mainly composed of clones, thus, each sample represents the genetic of a single plant. Most of the accessions of this forage plant have been obtained by cloning selected plants growing in favourable environments, by comparing with traditional varieties and cultivars resulting from breeding programs. Considering the area range and the environmental diversity of natural occurrence of elephantgrass in Africa (Brunken, 1977; Stapt \& Hubbard, 1934), as well as the rare germplasm collection records, it is likely that a significant part of the species variability is still unknown. Thus, the improvement of the species through the selection between accessions existing in the germplasm banks has extremely limited success chances.

\section{Population Hybridization and Improvement}

Elephantgrass is a species that produces seeds preferentially through cross-fertilization. Therefore, the same procedures recommended for other allogamous species can be used for elephantgrass genetic improvement (Simmonds \& Smartt, 1999). Similar to most of allogamous species with vegetative propagation, elephantgrass cultivars are highly heterozygous clones. Thus, the improvement based on the recombination of divergent genotypes carried out employing targeted crossings, selection, and cloning of progenies has successfully resulted in new cultivars (Figure 3).

Another improvement strategy is obtaining synthetic populations from the recombination of different variability sources, followed by recurrent selection to increase the frequency of favorable alleles. This method is mainly used to develop cultivars propagated through seeds, as it conserves variability within the population and consequently avoids inbreeding in the next generation. The improved populations can also be used for the selection of superior genotypes.

The use of genealogical control methods increases selective efficiency due to isolation of the environmental effects, contributing to greater genetic gains per selection cycle.

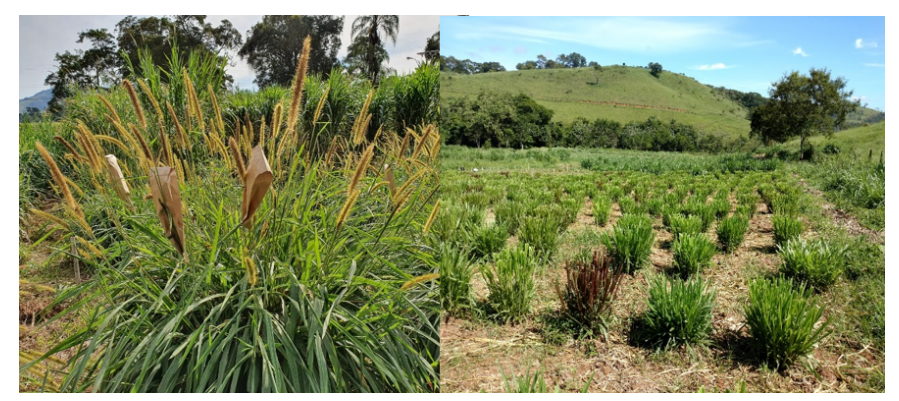

Figure 3. Obtaining of elephantgrass hybrids through controlled crosses and evaluation of segregating progenies.

\section{Interspecific Hybridization}

The genetic proximity between elephantgrass ( $P$. purpureum) and millet ( $P$. glaucum) facilitates the formation of hybrids. From this crossing, a sterile interspecific triploid hybrid results, which morphologically resembles elephantgrass and has some intermediate characteristics between the two parental species. Diz (1994) reported that the hybridization allows the combination of some of the desirable characteristics of the millet, such as forage quality, drought resistance, and disease tolerance, with rusticity, aggressiveness, longevity, and high dry matter productivity of the elephantgrass. According to Jauhar (1981) the forage of interspecific hybrids shows better acceptability by cattle.

Usually, millet is used as a female parent and elephantgrass as a male parent, given the greater ease of crossbreeding and the larger size of the seeds obtained. Although the triploid hybrid does not produce seeds due to chromosomal imbalance, it can be cloned and maintained through vegetative propagation. In addition, the hexaploid hybrids of elephantgrass $x$ millet, obtained by duplicating the chromosomes of the triploids, are considered an important alternative for developing cultivars propagated by seeds. 
Triploids and hexaploids are important sources of variation for selecting improved clones. However, most of these hybrids have early flowering and a semi-perennial vegetative cycle, considered undesirable characteristics.

\section{Main Cultivars}

There are many elephantgrass varieties under cultivation in Brazil, and the most traditional are the Napier, Cameroon, Mineiro, and Roxo cultivars. From the recent releases of cultivars, traditional varieties have been increasingly replaced by improved ones with higher yield and nutritive value. The main cultivars in use are:

BRS Capiaçu - Cultivar released by Embrapa in 2014. It is tall forage grass that can reach over $4.0 \mathrm{~m}$, and presents green, wide, and long leaves, absence of hair in adulthood, thick stems, and long internodes. The tussocks are erect with a high tiller density (average of 30 tillers $/ \mathrm{m}^{2}$ ) and potential of total dry matter production of $50 \mathrm{t} / \mathrm{ha} /$ year. The cultivar has vegetative propagation through cuttings and is indicated for supplementary feeding in the form of silage or grass stocking piles.

BRS Kurumi - Cultivar released by Embrapa in 2012. It has high forage production potential (30 t/ha/year of dry matter), high nutritional value (18 and $20 \%$ crude protein and in vitro dry matter digestibility between 68 and 70\%), high leaf/stem ratio, and ease of handling due to the small size. The cultivar is propagated through vegetative cuttings and is recommended for grazing in rotational stocking systems and use as green chop and silage.

BRS Canará - This cultivar released by Embrapa in 2012 is characterized by having a tall size, semi-open tussocks, green leaves, yellowish-green sheath, and medium diameter stems. It has vegetative propagation through cuttings and is indicated for silage or green chop. It is well adapted to the Amazon and Cerrado biomes.

Pioneiro - The cultivar was released by Embrapa in 1996. It has open-shaped tussocks, a large number of aerial and basal buds, thin stems, and erect leaves. Flowering is early, and in the winter months, it produces thinner and shorter leaves. It has an intermediate size and can be used in the cutting or rotational stocking system.

Cameroon - Cultivar introduced in Brazil in the 1960s. The tussocks are erect, and it measures up to $3 \mathrm{~m}$ in height high. The stems are thick, hairy, and with adventitious roots; the leaves are long, wide, and hairy on the upper blade side. Flowering is late. It has a production potential of up to $40 \mathrm{t} /$ ha/year and is recommended for silage and green chop.

Roxo - Cultivar introduced from the Republic of Togo with purple leaves. It has semi-open tussocks, reaching up to 3.80 $\mathrm{m}$ in height. The stems are thick; the purple leaves are wide and long, with hair on the upper blade side. The cultivar can be used for silage or as green chopped forage.

Napier - The first elephantgrass cultivar introduced in Brazil in 1920. It is one of the most traditional varieties and has the largest cultivated area. It has tussocks with a semiopen shape, and it can reach a height of up to five meters. The stems have a medium diameter and long internodes. The leaves are long and hairy on the upper blade side.

Mineiro - The cultivar was the first variety selected in Brazil obtained from progenies of half-siblings of the cultivar Napier. The cultivar Mineiro is similar to the cultivar Napier, with a height of up to $3.80 \mathrm{~m}$ and open tussocks. The stems present adventitious roots, and the leaf blades exhibit sparse hair distributed on the upper and lower sides. It has a high capacity for dry matter production and vigorous tillering, with a predominance of aerial tillers.

\section{Pests}

Several insect species attack the elephantgrass and sporadically can reach the pest status. The most frequent records are related to the small mocis moth or striped grass looper [Mocis latipes (Guenée)], fall armyworm [Spodopera frugiperda (J.E. Smith)], termites (Cornitermes sp.), heteropterans (Collaria oleosa), and ants [Atta capiguara (Gonçalves) and Atta bisphaerica (Forel)].

The pasture spittlebugs are the main crop pests due to the serious damage caused in the forage yield and quality, which may impact beef and dairy cattle production. Notozulia entreriana (Berg), Deois schach (Fabricius), Mahanarva fimbriolata (Hom.), and Mahanarva liturata (LePeltier \& Serville) are the main spittlebugs that attack elephantgrass. However, pasture spittlebugs of the genus Mahanarva have been the most prevalent, causing the greatest economic losses. According to Holmann \& Peck (2002), pastures with a high level of spittlebug infestation ( 50 adults $\mathrm{m}^{-2}$ ) may suffer a reduction of up to $54 \%$ in forage yield.

The control of pasture spittlebugs faces great challenges due to the following factors: lack of resistant cultivars; the high diversity of pest species and plant's resistance mechanisms that make obtaining horizontal resistance complex (Pereira et al., 2021). The fact that several other crops and forages, such as Brachiaria sp. syn. Urochloa sp. and sugarcane (Saccharum sp.), are attacked by the same species and can serve as hosts for the pest; and climatic conditions for most of the year in Brazil that favor the development of these insects.

In areas with a history of attack of spittlebugs it is recommended to monitor the stocking pile and pasture, aiming to define the appropriate time to start the control. Auad et al. (2007) indicated that the best pest control strategy is to integrate several control practices, inluding biological, cultural, and chemical control.

According to Valério (2009), the spittlebug attack contributes to pasture degradation impacting the nutritional status of the plant and the potential of regrowth at different harvest management. It has been reported that wellestablished and fertilized pastures managed under proper management conditions, show greater tolerance to attack by Mahanarva spectabilis (Distant) (Alvarenga et al., 2019). 


\section{Diseases}

Various diseases caused by fungi, bacteria, viruses, and other organisms have been reported in elephantgrass (Farrel et al., 2002; Charchar et al., 2008; Asudi et al., 2015). Most of them cause minor damage, not even leading to economic losses. The most common diseases are Helminthosporium leaf blight caused by the fungi Helminthosporium sacchari and Helminthosporium ocellum, and anthracnose caused by the fungus Colletotrichum graminicola, which can reduce forage yield and quality, and persistence. The symptoms are observed mainly in older leaves, with more than 100 days of growth. These diseases have limited impact since the grass is usually harvested before leaves get damaged.

In Brazil, there have been no records of serious diseases causing economic damage to elephantgrass. In Africa, two diseases cause severe damage to this forage plant: the Napier grass smut caused by the fungus Ustilago kamerunensis and the Napier grass stunt caused by a phytoplasma (Farrell et al., 2002; Asudi et al., 2015). These diseases cause serious damage to forage production, and the best form of controlling them by developing resistant cultivars (Kawube et al., 2014). Considering the serious risk that these diseases represent to the cultivation of this important forage plant, special care is needed to avoid introducing these pathogens in Brazil.

\section{Cultivation of Elephantgrass}

The good establishment of the pasture is the initial step toward greater longevity, increasing the potential for competition with other plant species. The plant stand influences the leaf area index and, consequently, the light interception.

Elephantgrass is a tall grass that favors competition with other plants; however, since it forms tussocks, the pastures end up with empty spaces between tussocks, facilitating weed growth. For this reason, good pasture formation, maintenance of soil fertility, and management allowing a rapid regrowth after grazing and canopy closure are essential.

\section{Cultivation Establishment}

Most elephantgrass cultivars are established by vegetative propagation using mature stems cuttings. About five to six tons of stems are needed per hectare for planting, with one hectare of nursery producing seedlings for planting six to eight hectares per cutting (Martins \& Fonseca, 1998). The stems cuttings for planting must be between 100 and 120 days of age, when they have the best bud-sprouting rate.

Areas with fertile soils and the possibility of implementing mechanization and irrigation should be preferably chosen to establish elephantgrass crops. In the selection of areas for stocking piles, the conditions need to facilitate the transport of the harvested forage, the filling of the silos, and organic fertilization. Wet floodplain areas or areas prone to flooding should be avoided, as the plant does not tolerate waterlogged soils.
Planting must be carried out during the rainy season, with the stem distributed in planting pits or furrows, and covered by a soil layer of $15-20 \mathrm{~cm}$. The recommended spacing between rows varies from 0.50 to $1.20 \mathrm{~m}$, depending on the cultivar, form of use (stocking pile or grazing), and the harvest type (manual or mechanized). The narrower spacing promotes faster soil coverage, reducing the weed growth between the inter rows; however, plants tend to have thinner stems and are more prone to lodge. The larger spacing is intended to prevent the tractor wheels from passing over the rows during mechanized harvesting.

The stems must be overlapped in the furrows in a "footwith-tip" system. Cutting the stems into pieces of about $70 \mathrm{~cm}$ in height promotes better bud sprouting. Covering the furrows with soil can be performed with a tractor or hoe. Planting in pits is indicated for small or very steep areas that are difficult to mechanize. For this planting system, it is recommended to use two stem cuttings with 3-5 buds per planting pit.

\section{Fertilization}

According to Costa et al. (1990), for a production of $150 \mathrm{t} /$ ha/year of green matter ( $30 \mathrm{t} \mathrm{ha}^{-1}$ dry matter), elephantgrass extracts $480 \mathrm{~kg}$ of $\mathrm{N}$ from the soil; 117 of $\mathrm{P}_{2} \mathrm{O}_{5} ; 360$ of $\mathrm{K}_{2} \mathrm{O}$, and $168 \mathrm{~kg}$ of $\mathrm{CaO}$. Thus, to maintain the productivity and longevity of the grass stocking piles, it is necessary to use chemical and organic fertilizers.

In most tropical soils, the main limitations are acidity and low phosphorus levels (Monteiro, 1997), which needs to be corrected using liming and fertilizers. To determine the need for correcting soil fertility, soil analysis is recommended. The amount of limestone must be sufficient to reach, at least, $60 \%$ base saturation. The limestone must be distributed in the area at least 60 days before planting, followed by soil plowing.

The application of phosphate fertilizer is recommended during planting, distributed at the bottom of the furrows or planting pits. The first cover fertilization with nitrogen and potassium should be carried out when the plants reach an average height of $50 \mathrm{~cm}$. The fertilizers can be mixed and applied after each harvest, or into three applications (beginning, middle, and end of the rainy season), always with moist soil.

The organic fertilization with manure reduces the need for chemical fertilizers and contributes do increased yield. It is recommended to use up to $50 \mathrm{t} / \mathrm{ha} /$ year of organic fertilizer distributed directly on the surface after harvest the stocking pile, regardless of the time of year (Cóser \& Pereira, 2001).

\section{Irrigation}

Irrigation is a practice that can contribute both to increase yield and to reduce the seasonality of forage production. Thus, water replacement through irrigation, in the appropriate amount and at the appropriate time, reflects positively on the forage yield. However, its intensity is dependent on the limitation of climatic factors, mainly temperature and light.

When associated with irrigation, nitrogen fertilization is decisive in the development of the root system. The adequate 
root develop may allow a quick restoration of the leaf area index and tillering after harvesting, which contributes to greater interception of the incident light and, consequently, a higher rate of grass growth than weeds, and contribute to an indirect increase in the rate of water assimilation by the grass (Alencar et al., 2010).

\section{Main Usages}

Elephantgrass, in addition to having high yield potential, can be used in various ways in animal feeding. The most common usages are:

\section{Grass stocking piles - Green Chop}

Grass stocking piles are a forage resource to supplement the pasture with fresh forage in the dry or cold season. However, at these times, the forage production of most elephantgrass cultivars represents only $15-20 \%$ of total annual forage production. In general, early flowering cultivars have a greater reduction in leaf production during the dry season (Pereira, 1993). Thus, the use of late-flowering cultivars is recommended for stocking piles since they have a better distribution of forage production throughout the year.

When establishing grass stocking piles, it is recommended the use of upright growth cultivars with high degree of basal tillering. The hairy cultivars should be avoided due to the discomfort caused to the worker when harvesting and transporting the forage.

For traditional cultivars (Napier, Mineiro, Cameroon), the grass to be used as green chopped must be cut close to the ground level when the plant reaches about $1.80 \mathrm{~m}$ in height, or every 60 days in the summer, or when it reaches $1.50 \mathrm{~m}$ high in winter (Cóser et al., 1999). This management aims to reach the best relationship between quantity and quality of forage since its yield and nutritional value are generally affected by the age of the plant. It is important to mentions that cutting the grass at an older age than recommended, despite providing greater dry matter production, results in a reduction in the forage nutritive value due to the increase in the fibrous fraction and the decrease in the protein content, which may affect animal production.

The general management recommendation for BRS Capiaçu for use as green chop is harvesting at the interval of 50 to 70 days. Under these conditions, plant height ranges from 2.4 to $2.9 \mathrm{~m}$, dry matter production varies from 5.1 to $13.3 \mathrm{t} / \mathrm{ha} / \mathrm{cutting}$, and crude protein levels from 9.7 to $7.7 \%$, respectively (Pereira et al., 2016).

\section{Silage}

One of the main ways of using elephantgrass is to produce silage due to the high forage production potential and the lower cost compared to other forage options. One of the critical points in the production of both silage and hay is the high moisture content when the forage has the best nutritive value. The withering of silage forage is an option to reduce this limitation and has the advantage of increasing the dry matter content and carbohydrates concentrations. The withering process, however, increases the costs.

Like most tropical grasses, elephantgrass is characterized by low contents of dry matter and soluble carbohydrates at the age when it has the best nutritional value of forage. Biomass silage with high moisture content affects the fermentation process in the silo, and increases losses by effluents (Bernardes \& Rego, 2014). The inclusion of drying additives such as citrus pulp, cornmeal, husk, and soy molasses, among others, to raise the dry matter content and increase the concentration of fermentable carbohydrates is an alternative to improve the silage fermentation pattern and the nutritive value (Paula et al., 2020). However, the inclusion of additives also increases the cost of silage production. The inclusion of these additives needs to take into account the final cost of the silage produced ( $R \$ \mathrm{~kg}^{-1}$ of dry matter) compared to the production cost of traditional silages (e.g., corn and sorghum), as well as the amount of concentrated supplement needed in each case.

To avoid these problems, elephantgrass harvesting, and silage must be carried out when the plant is older to obtain the best relationship between biomass production, nutritive value, and dry matter content. In the case of the BRS Capiaçu cultivar, the best relationship between biomass, nutritive value, and dry matter content is achieved when the forage is harvested after 90-110 days of regrowth (Figure 4, Table 1) (Pereira et al., 2021). The harvest elephantgrass for silage at an older age (above 120 days of regrowth) results in silage with low nutritive value.

Elephantgrass silage generally shows lesser nutritive value when compared to corn and sorghum silages. This implies the need to provide a greater amount of concentrate in the diet to meet the nutritional requirements of the animals. However, the additional cost with the use of a greater amount of concentrate in the diet can be offset by the lower cost of elephantgrass silage.

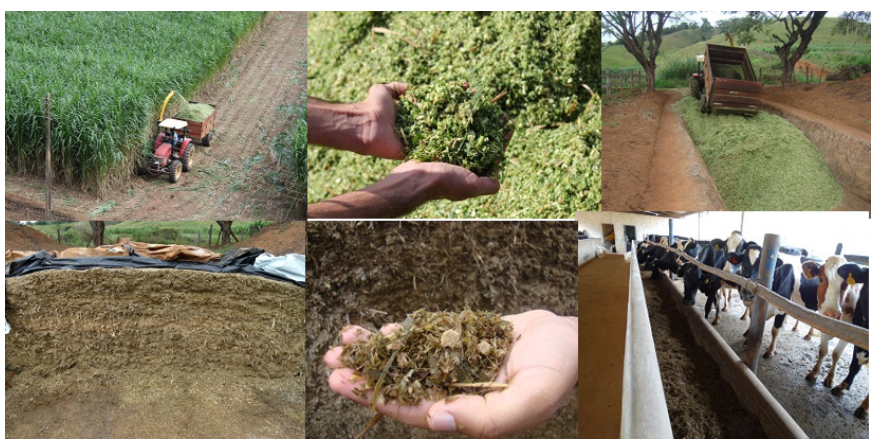

Figure 4. Harvest and silage of elephantgrass BRS Capiaçu.

Table 1. Chemical composition ${ }^{1}$ of elephantgrass silage, cultivar BRS Capiaçu, at two harvest ages.

\begin{tabular}{ccccccc}
\hline $\begin{array}{c}\text { Cutting age } \\
\text { (days) }\end{array}$ & $\begin{array}{c}\text { DM } \\
\text { (\%) }\end{array}$ & CP $^{2}$ & NDF $^{3}$ & LIG $^{4}$ & TDN $^{5}$ & pH \\
\hline 90 & 18.0 & 5.3 & 72.2 & 7.6 & 46.8 & 3.9 \\
110 & 20.4 & 5.1 & 73.8 & 9.0 & 45.4 & 3.8 \\
\hline
\end{tabular}

${ }^{1}$ Dry matter base; ${ }^{2}$ Crude protein; ${ }^{3}$ Neutral detergent fiber; ${ }^{4}$ Lignin; ${ }^{5}$ Total digestible nutrients. 


\section{Grazing}

The use of tall cultivars for grazing may restrict the management, since it may require periodic mowing. This contributed to the selection and release of the dwarf cultivar BRS Kurumi, specifically for grazing. This cultivar presents high basal tillering, short internodes, and low stem elongation, favoring its use under grazing conditions (Gomide et al., 2011).

While research advances in developing improved genotypes, grazing management practices have also been improved to take advantage of the high yield and nutritive value of the BRS Kurumi, reducing the need for mechanical control (mowing) of the canopy structure (Gomide et al., 2011; Sousa et al., 2012; Chaves et al., 2013; Pereira et al., 2016) (Figure 5).

Rotational stocking is the main stocking method recommended for elephantgrass, and in this sense, three fundamental aspects need be considered: the definition of the rest period, the height of entry of the animals, the stubble height (post-grazing residual height), and the grazing period (occupation of the paddocks).

For dwarf cultivars such as BRS Kurumi and Mott, the recommended pre-graze heights vary between 75 and $80 \mathrm{~cm}$, with stubble height of 30 to $40 \mathrm{~cm}$. Under these management conditions, the grass has shown higher values of leaf/stem ratio and rate of forage accumulation, in addition to lower leaf senescence and the best nutritive value (Paciullo et al., 1998; Gomide et al., 2015; Pereira et al., 2021).

Normally, the grazing period varies between one and three days (Cóser et al., 1999), and the rest period may differ among seasons, and must be based on the plant height during pre-grazing. Currently, intensive production systems, both in elephantgrass and other grasses, have adopted a grazing period of one day under rotational stocking to obtain greater uniformity in the nutritional value of forage consumed during grazing. However, this alternative results in a greater number of paddocks, leading to greater initial investment.

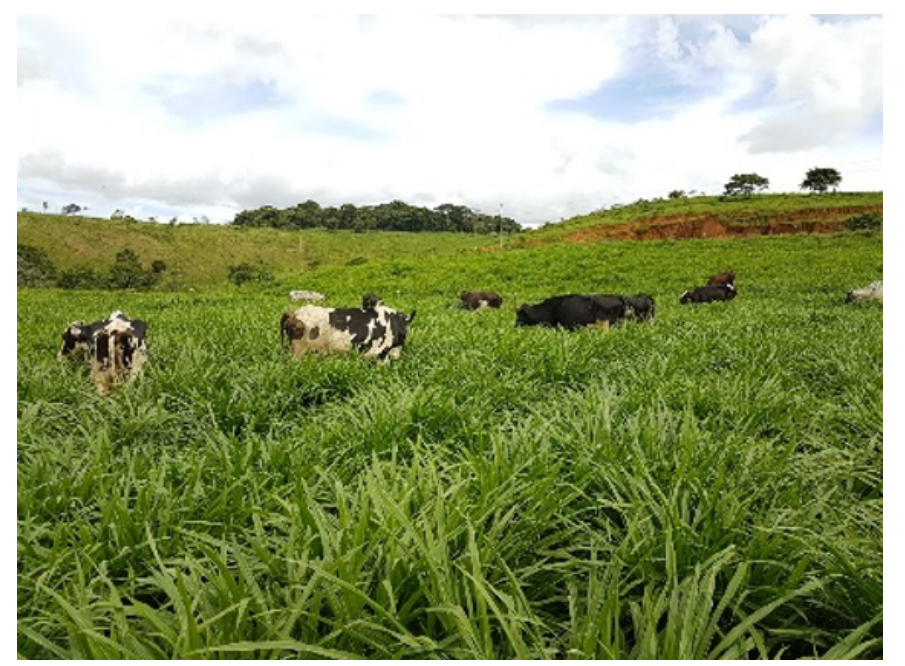

Figure 5. Pasture of the dwarf cultivar BRS Kurumi.

\section{Biomass Energy}

Elephantgrass, among the crops dedicated to energy production from biomass, is considered a good alternative due to its photosynthetic efficiency, high yield potential, perennial and rapid growth, wide adaptation, and BNF capacity in addition to its chemical properties. Despite this, the use of elephantgrass as a source of bioenergy requires selecting genetic material with characteristics different from those traditionally used for animal feed. High carbon/nitrogen ratio, high yield potential, and low protein content are some of the requirements for minimal consumption of fossil energy.

Despite the potential use of elephantgrass as a biomass energy source, there are challenges to be overcome. The main ones are related to biomass production, considering: i) specific cultivars for energy production have not yet been developed; ii) there is no agronomic model like spacing, fertilization, harvesting, or biomass storage, among others, defined with a focus on energy use, especially considering large-scale cropping systems.

\section{Other Usage Forms}

There are other possibilities of using elephantgrass in agriculture with economic advantages concerning other types of raw material. Among the main forms of non-forage use are as straw for no-till farming, poultry litter, and in the compost barn system for dairy cattle production.

The use of elephantgrass as a straw for no-till farming has the advantages of producing high dry matter content and quality biomass, be easily desiccated with the use of herbicides, and does not leave a dormant seed bank in the soil.

This biomass can be used as a poultry litter and in the compost barn system. Although the dry matter in elephantgrass is more rapidly degraded than materials such as wood shavings and rice husks, it can be easily produced at a low cost.

\section{Final Comments and Remarks}

Elephantgrass shows high yield potential, good nutritive value, adaptive capacity to different environmental conditions, and versatility in forage usage. These characteristics make the species one of the most important tropical forage grasses cultivated worldwide.

Research advances mainly in genetic improvement and management have enabled a significant increase in the use of this forage plant for different purposes. Among the breeding research priorities, the cultivars for silage production, grazing, and biomass energy production stand out. Characteristics such as resistance to spittlebugs and seed propagation are highly desirable in new cultivars.

Developing cultivars for non-forage uses, such as biomass energy production, has great potential to expand the economic exploitation of this tropical grass. Research in the fields of pasture management improvement, silage production, and pest control are also high priorities. 


\section{Acknowledgments}

The present review on elephantgrass is dedicated to Prof. Mário de Andrade Lira (in memoriam) for his pioneering and tireless work to disseminate this forage plant, as well as for his great contribution to science that resulted in greater scientific knowledge and development of this forage crop in Brazil. His academic contribution was also very important by sharing knowledge and advised thousands of new professionals and researchers who, based on his teachings, have contributed to the development of Brazilian agriculture. Recognized as a model of dedication to work, admired by colleagues, students, and producers, Prof. Lira was an example of a professional and human being. To him and his family, the homage of all the authors.

\section{Compliance with Ethical Standards}

Conflict of interest: The authors declare that they have no conflict of interest.

Funding: Not applicable.

\section{Literature Cited}

Alencar, C.A.B.; Cóser, A.C.; Martins, C.E.; Oliveira, R.A. Altura de capins e cobertura do solo sob adubação nitrogenada, irrigação e pastejo nas estações do ano irrigação e pastejo nas estações do ano. Acta Scientiarum, Agronomy, v. 32, n.1, p. 21-27, 2010. https://doi.org/10.4025/actasciagron.v32i1.319.

Alvarenga, R.; Auad, A. M.; Moraes, J. C.; Silva, S. E. B.; Rodrigues, B. S. Tolerance to nymphs and adults of Mahanarva spectabilis (Hemiptera: Cercopidae) by forage plants in fertilized soils. Pest Management Science, v.76, n.8, p.2242-2250, 2019. https://doi. org/10.1002/ps.5361.

Animasaun, D. A.; Morakinyo, J. A.; Mustapha, O.T.; Krishnamurthy, R. Genome size and ploidy variations in pearl millet (Pennisetum glaucum) and napier grass (Pennisetum purpureum) genotypes. Acta Agronómica, v. 68, n.4, p. 299-305, 2019. https://doi. org/10.15446/acag.v68n4.75939.

Asudi, G.O.; Berg, J.V.D.; Midega, C.A.O.; Pittchar, J.; Pickett, J.A.; Khan, Z.R. Napier grass stunt disease in East Africa: Farmers' perspectives on disease management. Crop Protection, v.71, p. 116 - 124, 2015. https://doi.org/10.1016/j.cropro.2015.02.008.

Auad, A.M.; Resende, T.T.; Fonseca, M. G; Santos, J. C. Controle estratégico de pragas em pastagem. In: Simpósio de Produção Animal a Pasto, 2., 2013, Londrina. Anais... Londrina: Sthampa, 2013. v. 1, p. 267-288.

Barbosa, S.; Davide, L.C.; Pereira, A.V. Cytogenetics of Pennisetum purpureum Schumack $x$ Pennisetum glaucum L. hybrids and their parents. Ciência e Agrotecnologia, v. 27, n.1, p. 23-26, 2003. https://doi.org/10.1590/S1413-70542003000100003.

Bernardes, T.F.; Rêgo, A.C. Study on the practices of silage production and utilization on Brazilian dairy farms. Journal of Dairy Science, v.97, n.3, p.1852-1861, 2014. https://doi.org/10.3168/jds.2013-7181.

Bogdan, A.V. Tropical pastures and fodder crops. New York: Longman, 1977. $475 \mathrm{p}$.
Boonman, J.G. East Africa's grasses and fodders: their ecology and husbandry. Dordrecht: Kluwer Academic, 1993. 343p. (Tasks for Vegetation Science, 29). https://doi.org/10.1007/978-94-0158224-7.

Breseghello, F.; Coelho, A.S.G. Traditional and modern plant breeding methods with examples in rice (Oryza sativa L.). Journal of Agricultural and Food Chemistry, v.61, n.35, p.8277-8286, 2013. https://doi.org/10.1021/jf305531j.

Brunken, J.N. A systematic study of Pennisetum Sect. Pennisetum (Gramineae). American Journal of Botany, v. 64, n. 2, p. 161-176. 1977. https://doi.org/10.1002/j.1537-2197.1977.tb15715.x.

Cavalcante, M.; Lira, M. de A. Variabilidade genética em Pennisetum purpureum Schumacher. Revista Caatinga, v. 23, n. 2, p. 153163, 2010. https://periodicos.ufersa.edu.br/index.php/caatinga/ article/view/1230. 10 Jan. 2021

Charchar, M.J.A; Anjos, J.R.N.; Silva, M.S.; Mello Silva, W.A.M. Mancha foliar em capim-elefante no Cerrado do Brasil Central causada por Bipolaris maydis. Pesquisa Agropecuária Brasileira, v.43, n.11, p.1637-1639, 2008. https://doi. org/10.1590/S0100-204X2008001100025.

Chaves, C.S.; Gomide, C.A.M.; Ribeiro, K.G.; Paciullo, D.S.C.; Ledo, F.J.S.; Costa, I.A.; Campana, L.L. et al. Forage production of elephant grass under intermittent stocking. Pesquisa Agropecuária Brasileira, v. 48, n.2, p. 234-240, 2013. https://doi. org/10.1590/S0100-204X2013000200015.

Chemisquy, M.A.; Giussani, L.M.; Scataglini, M.A.; Kellogg, E.A.; Morrone, O. Phylogenetic studies favour the unification of Pennisetum, Cenchrus and Odontelytrum (Poaceae): a combined nuclear, plastid and morphological analysis, and nomenclatural combinations in Cenchrus. Annals of Botany, v.106, n.1, p.107130, 2010. https://doi.org/10.1093/aob/mcq090.

Coombs, J.; Baldry, C.W.; Brow, J.E. The C-4 pathway in Pennisetum purpureum. III. Structure and Photosynthesis. Planta, v.110, n.2, p.121-129. 1973. https://doi.org/10.1007/BF00384834.

Cóser, A.C.; Pereira, A.V. Forrageiras para corte e pastejo. Juiz de Fora: Embrapa Gado de Leite, 2001. 37p. (Embrapa Gado de Leite. Circular Técnica, 66). https://ainfo.cnptia.embrapa.br/digital/ bitstream/item/81889/1/Forrageiras-para-corte.pdf. 07 Dec. 2020.

Costa, N.L.; Magalhães, J.A.; Pereira, R.G.A. Formação e manejo de capineiras em Rondônia. Porto Velho: Embrapa Rondônia, 1990. 23p. (Embrapa Rondônia. Comunicado Técnico, 93).

Diz, D.A. Breeding procedures and seed production management in pearl millet $x$ elephant grass hexaploid hybrids. Florida: University of Florida, 1994. 118 p. PhD Thesis. https://ufdc.ufl. edu/AA00038008/00001/1x. 12 Oct. 2020.

Dujardin, M.; Hanna, W. W. Cytology and reproductive behavior of pearl millet-napiergrass hexaploids $x$ Pennisetum squamulatum triespecif hybrids. The Journal of Heredity, v. 76, n.5, p. 382-384, 1985.

Evangelista, A. R.; Rocha, G. P. Forragicultura. Lavras: ESAL, 1990. $184 p$.

Farrell, G.; Simons, S. A.; Hillocks, R. J. Pests, diseases and weeds of Napier grass, Pennisetum purpureum: a review. International Journal of Pest Management, v.48, p.39-48, 2002. https://doi. org/10.1080/09670870110065578. 
Ferraris, R.; Mahony, M.J.; Wood, T.T. Effect of temperature and solar radiation on the development of dry matter and attributes of elephant grass (Pennisetum purpureum Schum.). Australian Journal of Agricultural Research, v.37, n.6, p.621-632, 1986. https://doi.org/10.1071/AR9860621.

Fonseca, D.M.; Martuscello, J.A. Adubação e Fertilidade do solo em capim-elefante. In: Lira, M.A.; Santos, M.V.F.; Dubeux Junior, J.C.B.; Mello, A.C.L. (Eds.). Capim-elefante: fundamentos e perspectivas. Recife: IPA; UFRPE, 2010. p.113-144.

Gomide, C.A.M.; Paciullo, D.S.C.; Lédo, F.J.S.; Castro, C.R.T.; Morenz, M.J.F. Produção de forragem e valor nutritivo de clones de capim-elefante anão sob estratégias de desfolha intermitente. Juiz de Fora: Embrapa Gado de Leite, 2011. 23p. (Embrapa Gado de Leite. Boletim de Pesquisa e Desenvolvimento, 31). https:// ainfo.cnptia.embrapa.br/digital/bitstream/item/57079/1/BOP31-Prod-forragem.pdf. 12 Oct. 2020.

Gomide, C.A.M.; Paciullo, D.S.C.; Ledo, F.J.S.; Pereira, A.V.; Morenz, M.J.F.; Brighenti, A.M. Informações sobre a cultivar de capimelefante BRS Kurumi. Juiz de Fora: Embrapa Gado de Leite, 2015. $4 p$ (Embrapa Gado de Leite. Comunicado Técnico, 75). https:// ainfo.cnptia.embrapa.br/digital/bitstream/item/124202/1/ Informacoes-Tecnicas-sobre-a-cultivar-de-capim-elefante-BRSKurumi-COT-75.pdf. 05 Nov. 2020.

Gonzalez, B.; Hanna, W.W. Morphological and fertility responses in isogenic triploid and hexaploid pearl millet $x$ napier-grass hybrids. Journal of Heredity, v. 75, n.4, p. 317-318, 1984. https://doi.org/10.1093/oxfordjournals.jhered.a109945.

Granato, L. O. Capim-elefante (Pennisetum purpureum Schum.). São Paulo: Secretaria de Agricultura, 1924. 96p.

Gutiérrez, H.F. The American species of the genus Cenchrus s.l. (Poaceae, Panicoideae, Paniceae). Darwiniana, nueva serie, v.3, n.1, p.14-200, 2015. http://www.ojs.darwin.edu.ar/index.php/ darwiniana/article/view/641/645. 12 Oct. 2020.

Hanna, W. W. Method of reproduction in napiergrass and in the $3 X$ and $6 \mathrm{X}$ alloploid hybrids with pearl millet. Crop Science, v. 21, n.1, p. 123-126, 1981. https://doi.org/10.2135/cropsci1981.00 11183X002100010033x.

Hanna, W. W.; Gaines, T. P.; Gonzalez, B.; Monson, W. G. Effect of ploidy on yield and quality of pearl millet $x$ napier grass hybrids. Agronomy Journal, v. 76, n. 6, p. 969-971, 1984. https://doi. org/10.2134/agronj1984.00021962007600060024x.

Hanna, W.W.; Chaparro, C.J.; Mathews, B.W.; Burns, J.C.; Sollenberger, L.E. Perennial Pennisetums. In: Moser, L.E.; Burson, B.L.; Sollenberger, L.E. (Eds.). Warm-season (C4) Grasses. Madison: ASA; CSSA; SSSA, 2004. Chap. 14, p.503545. (Agronomy Monograms, 45). https://doi.org/10.2134/ agronmonogr45.c14.

Harlan, J.R.; De Wet, J.M.J. Toward a rational classification of cultivated plants. Taxon, v. 20, n.4, p. 509-517, 1971. https:// doi.org/10.2307/1218252.

Holmann, F.; Peck, D.C. Dano econômico da cigarrinha-daspastagens (Homoptera: Cercopidae) na Colômbia: primeira aproximação do impacto na produção animal em pastagens de Brachiaria decumbens. Neotropical Entomology, v.31, n.2, p.275-284, 2002. https://doi.org/10.1590/S1519566X2002000200016.
Jacques, A.V.A. Caracteres morfo-fisiológicos e suas aplicações como manejo. In: Carvalho, M.M., Alvim, M.J., Xavier, D.F. (Eds.). Capim elefante: produção e utilização. Coronel Pacheco: Embrapa-Gado de Leite, 1994. p.31-47.

Jauhar, P. P. Citogenetics and breeding of pearl millet and related species. New York: Alan R. Liss, 1981. 289p.

Kawube, G.; Otim, A. M.; Mukwaya, A.; Kabirizi, J.; Talwana, H. Resistance of Napier grass clones to Napier grass Stunt Disease. African Crop Science Journal, v.22, n.3, p.229-235, 2014. https:// www.ajol.info/index.php/acsj/article/view/107186. 07 Dec. 2020.

Kirchhof, G.; Reis, V.M.; Baldani, J.I.; Eckert, B.; Döbereiner, J.; Hartmann, A. Occurrence, physiological and molecular analysis of endophytic diazotrophic bacteria in gramineous energy plants. Plant and Soil, v.194, p.45-55, 1997. https://doi. org/10.1023/A:1004217904546.

Liang, X.; Erickson, J.E.; Sollenberger, L.E.; Rowland, D.L.; Silveira, M.L.; Vermerris, W. Growth and transpiration responses of elephantgrass and energycane to soil drying. Crop Science, v. 58, n.1, p. 354 - 363, 2018. https://doi.org/10.2135/ cropsci2017.01.0019.

Lira, M.A.; Cunha, M.V.; Pereira, A.V. Melhoramento genético do capim-elefante. In: Lira, M.A.; Santos, M.V.F.; Dubeux Junior, J.C.B.; Mello, A.C.L. (Eds.). Capim-elefante: fundamentos e perspectivas. Recife: IPA; UFRPE, 2010. p.31-48.

Maire, R. Flore de l'Afrique du Nord. Paris: Paul Lechevalier, 1952. $276 p$.

Martel, E.; Poncet, V.; Lamy, F. Siljak-Yakovlev, S.; Lejeune, B.; Sarr, A. Chromosome evolution of Pennisetum species (Poaceae): implications of ITS phylogeny. Plant Systematics and Evolution, v. 249, n. 3-4, p. 139-149. 2004. https://doi.org/10.1007/s00606004-0191-6.

Martins, C.E.; Fonseca, D.M. Manejo e fertilidade do solo em pastagens de capim-elefante. Informe Agropecuário, v.19, n.192, p.44-54, 1998.

Martins, C.E.; Rocha, W.S.D..; Souza Sobrinho, F.; Gomes, F.T.; Rocha, W.S.D.; Brighenti, A.M. Aluminum toxicity tolerance in elephantgrass. Pesquisa Aplicada \& Agrotecnologia, v.3, n.1, p. 103-109, 2010. https://revistas.unicentro.br/index.php/repaa/ article/view/655/1069. 12 Jan. 2021.

Monteiro, F.A. Adubação para o estabelecimento e manutenção de capim-elefante. In. In: Carvalho, M.M.; Alvim, M.J.; Xavier, D.F.; Carvalho, L.A. (Eds.). Capim-elefante: produção e utilização. Coronel Pacheco: EMBRAPA-CNPGL, 1997. p. 49-79.

Morais, R.F.; Morais, C.S.B.; de Morais, L.F.; Almeida, J.C.C. Energy balance of elephant grass biomass for power generation by direct biomass combustion. African Journal of Biotechnology, v.17, n.13, p.405-410, 2018. https://doi.org/10.5897/AJB2018.16385.

Morais, R.F.; Quesada, D.M.; Reis, V.M.; Urquiaga, S.; Alves, B.J.R.; Boddey, R.M. Contribution of biological nitrogen fixation to Elephant grass (Pennisetum purpureum Schum.). Plant and Soil, v. 356, p. 23-34, 2012. https://doi.org/10.1007/s11104-0110944-2.

Oliveira, A.L.M.; Urquiaga, S.; Dobereiner, J.; Baldani, J.I. The effect of inoculating endophitic N2 -fixing bacteia on micropropagated sugarcane plants. Plant and Soil, v.242, p. 205-215, 2002. https:// doi.org/10.1023/A:1016249704336. 
Osgood, R.V.; Hanna, W.W.; Tew, T.L. Hybrids seed production or pearl millet $x$ napiergrass triploid hybrids. Crop Science, v. 37, n.3, p. 998-999, 1997. https://doi.org/10.2135/cropsci1997.0011183X0 03700030049x.

Paciullo, D.S.C.; Gomide, J.A.; Ribeiro, K.G. Adubação nitrogenada do capim-elefante cv. Mott. 1. Rendimento forrageiro e características morfofisiológicas ao atingir 80 e $120 \mathrm{~cm}$ de altura. Revista Brasileira de Zootecnia, v.27, n.6, p.1069-1075, 1998.

Paula, P.R.P.; Neiva Júnior, A.P.; Souza, W.L.; Abreu, M.J.I.; Teixeira, R.M.A.; Cappelle, E.R.; Tavares, V.B. Composição bromatológica da silagem de capim-elefante BRS Capiaçu com inclusão fubá de milho, Pubvet, v.14, p.1-11, 2020. https://www.pubvet.com.br/ uploads/cabf8e85bff1c94b1cbd089c0c745012.pdf. 15 Dec. 2020.

Pereira, A.V. Escolha de variedades de capim-elefante. In: Simpósio sobre manejo de pastagem, 10., 1992, Piracicaba. Anais... Piracicaba: FEALQ, 1993. p. 45-62.

Pereira, A.V.; Auad, A.M.; Santos, A.M.B; Mittelmann, A.; Gomide, C.A.M.; Martins, C.E.; Paciullo, D.S.C.; Lédo F.J.S.; Oliveira, J.S.; Leite, J.L.B.; Machado, J.C.; Matos, L.L.; Morenz, M.J.; Andrade, P.J.M.; Bender, S.E.; Rocha, W.S.D. BRS Capiaçu e BRS Kurumi: cultivo e uso. Brasília: Embrapa, 2021. 124 p.

Pereira, A.V.; Barra, R.B.; Abreu, J.C.; Freitas, V.P.; Souza, J.A.G. Protoginous interval in elephantgrass (Pennisetum purpureum Schum.). In: International Grasslands Congress, 18., 1997, Winnipeg. Proceedings... Winnipeg: Canadian Forage Council; Canadian Society of Agronomy; Canadian Society of Animal Science, 1999. v.3, p.123-126.

Pereira, A.V.; Ledo, F.J.S.; Morenz, M.J.F.; Leite, J.L.B.; Santos, A.M.B.; Martins, C.E.; Machado, J.C. BRS Capiaçu: cultivar de capimelefante de alto rendimento para produção de silagem. Juiz de Fora: Embrapa Gado de Leite, 2016. 6p. (Embrapa Gado de Leite, Comunicado Técnico, 79). https://www.infoteca.cnptia.embrapa. br/infoteca/bitstream/doc/1056288/1/ComunicadoTecnico79. pdf. 12 Dec. 2020.

Pereira, A.V.; Lédo, F.J.S.; Machado, J.C. BRS Kurumi and BRS Capiaçu New elephant grass cultivars for grazing and cut-and-carry system. Crop Breeding and Applied Biotechnology, v.17, n.1, p. 59-62, 2017. https://doi.org/10.1590/1984-70332017v17n1c9.

Pereira, A.V.; Valle, C.B. do; Ferreira, R.P.; Miles, J.W. Melhoramento de forrageiras tropicais. In: Nass, L.L.; Valois, A.C.C.; Melo, I.S.; Valadares-Ingls, M.C. (Eds.). Recursos genéticos e melhoramentoplantas. Rondonópolis: Fundação Mato Grosso, 2001. p.550-601.

Quesada, D.M. Seleção de genótipos de capim-elefante (Pennisetum purpureum Schum.) para a alta produção de biomassa e eficiência da fixação biológica de nitrogênio (FBN). Seropédica: Universidade Federal Rural do Rio de Janeiro, 2001. 86p. Dissertação Mestrado. Reis, G.B.; Mesquita, A.T.; Torres, G.A.; Andrade-Vieira, L.F.; Pereira, A.V.; Davide, L.C. Genomic homeology between Pennisetum purpureum and Pennisetum glaucum (Poaceae). Comparative Cytogenetics, v. 8, n.3, p. 31-41, 2014. https://doi.org/10.3897/ CompCytogen.v8i3.7732
Rocha, J.R.A.S.C.; Machado J.C.; Carneiro, P.C.S.; Carneiro, J.C.; Resende, M.D.V.; Pereira, A.V.; Carneiro, J.E.S. Elephant grass ecotypes for bioenergy production via direct combustion of biomass. Industrial Crops and Products, v.95, p.27-32, 2017. https://doi.org/10.1016/j.indcrop.2016.10.014.

Rodrigues, L.R.A.; Rodrigues, T.J.D. Ecofisiologia de plantas forrageiras. In: Castro, P.R.C.; Ferreira, S.O.; Yamada, T. (Eds.). Ecofisiologia da produção agrícola. Piracicaba: Associação Brasileira para Pesquisa da Potassa e do Fosfato, 1997. p.203-230.

Simmonds, N. W.; Smartt, J. Principles of crop improvement, 2.ed. Oxford: Blackwell Science. 1999. 422 p.

Singh, B.P.; Singh, H.P.; Obeng, E. Elephantgrass. In: Singh, B.P. (Eds.). Biofuel crops: production, physiology and genetics. Wallingford: CAB International, 2013. Chap. 13, p.270-290. https://doi.org/10.1079/9781845938857.0271.

Sollenberger, L.E.; Prine, G.M.; Ocumpaugh, W.R.; Hanna, W.W.; Jones Junior, C.S.; Schank, S.C.; Kalmbacher, R.S. Registration of 'Mott' dwarf elephantgrass. Crop Science, v.29, n.3, p.827- 828. 1989. https://doi.org/10.2135/cropsci1989.0011183X002900 030062x.

Sousa, B.M.L. Nascimento Junior., D.; Monteiro, H.C.F.; Fonseca, D.M. Dynamics of production and forage utilization on elephant grass pastures managed with different post-grazing heights, Revista Brasileira de Zootecnia, v. 41, n.8, p.1840-1847, 2012. https://doi.org/10.1590/S1516-35982012000800006.

Stapt, O.; Hubbard, C.E. Pennisetum. In: Prain, D. (Eds.). Flora of tropical Africa. Ashford: Reeve, 1934. v.9, p.954-1070.

Tcacenco, F.A.; Botrel, M.A. Identificação e avaliação de acessos e cultivares de capim-elefante. In: Carvalho, M.M.; Alvim, M.J.; Xavier, D.F.; Carvalho, L.A. (Eds.). Capim-elefante: produção e utilização. Coronel Pacheco: EMBRAPA-CNPGL, 1997. p.1-30.

Tcacenco, F.A; Lance, G.N. Selection of morphological traits for characterization of elephant grass accessions. Tropical Grasslands, v.26, n.3, p.145-155, 1992.

Techio, V.H.; Davide, L.C.; Pereira, A.V.; Bearzoti, E. Cytotaxonomy of some species and of interspecific hybrids of Pennisetum (Poaceae, Poales). Genetics and Molecular Biology, v.25, n.2, p.203-209, 2002. https://doi.org/10.1590/S141547572002000200014.

Valério, J.R. Cigarrinhas-das-pastagens. Campo Grande: Embrapa Gado de Corte, 2009. 51p. (Embrapa Gado de Corte. Documentos,179). https://ainfo.cnptia.embrapa.br/digital/ bitstream/item/211564/1/Cigarrinhas-das-pastagens.pdf. 07 Dec. 2020.

Xavier, D.F.; Botrel, M.A.; Daher, R.F.; Gomes, F.T.; Pereira, A.V. Caracterização morfológica e agronômica de algumas cultivares de capim-elefante. Coronel Pacheco: EMBRAPA-CNPGL, 1995. 24 p. (EMBRAPA-CNPGL. Documentos, 60.). https://ainfo. cnptia.embrapa.br/digital/bitstream/item/143038/1/2058.pdf. 05 Nov. 2020. 